\title{
Solar energy and cultural-heritage values
}

\author{
Tor Broström ${ }^{1, *}$, Karin Svahnström ${ }^{1}$ \\ ${ }^{1}$ Gotland University, Centre for Energy Efficiency in Historic Buildings, Visby, Sweden \\ * Corresponding author. +46 498299 922., E-mail: tor.brostrom@hgo.se
}

\begin{abstract}
The use of solar energy in a building of cultural-heritage value is an issue that brings the trade-off between aspects of use and preservation to a head. A sustainable use and preservation of historic buildings requires broad and long term compromises between social, economic and environmental aspects. The objective of the present paper is to present and discuss a decision framework for such compromises regarding the use of solar energy in historic buildings.
\end{abstract}

Keywords: Solar energy, Renewable energy, Historic buildings, Cultural heritage

\section{Introduction}

The heavier demands that society now places on the efficient management of finite resources in general and energy in particular is bound to have consequences for our ability to use and thus preserve the built cultural heritage. When rising energy prices coincide with people's greater insistence on indoor comfort, all the more historically valuable buildings stand the risk of being insufficiently heated and, ultimately, either abandoned or vulnerable to damp, mould and vermin. Such a trend runs diametrically counter to the goal of long-term use and preservation of these buildings.

The use of solar energy in a building of cultural-heritage value is an issue that brings the trade-off between aspects of use and preservation to a head. On the one hand, solar energy facilitates long-term use as it makes it possible for buildings to be heated with renewable energy at a lower running cost; on the other hand, the visible installations - the solar collectors or solar cells - have a marked impact on their appearance and cultural heritage value. Conversely, while non-installation protects the buildings' cultural-heritage values, in the short term, there is a danger that such a decision will make them less attractive for longterm use and thus limit opportunities for their preservation. Economically and ecologically sustainable heating solutions must therefore be found that make it possible to use the buildings without jeopardising their cultural heritage value.

There is a general agreement that the use of solar energy in historic buildings must be considered carefully. The problem today is that decisions too often are based on relatively short term techno-economic and ecological considerations on one hand and considerations of vaguely defined cultural heritage values, with a focus on aesthetics, on the other hand.

A sustainable use and preservation of historic buildings requires broad and long term compromises between social, economic and environmental aspects. The decision context is multi-disciplinary and decisions are elaborated on the basis of both qualitative and quantitative data. There is therefore clearly a need for a structured approach to the decisionmaking which minimizes the risk for arbitrary and ad-hoc decisions which will have negative long-term impact on energy use, preservation or, in the worst case, both. The objective of the present paper is to present and discuss a simple decision framework for such compromises regarding the use of solar energy in historic buildings.

The cultural heritage can be seen as a cultural capital not unlike other forms of capital, with the important differences that it is possibly irreplaceable and its societal value is likely to be 
higher than its market value ${ }^{1}$. Given this irreplacability, the cultural heritage should be considered a non-renewable national resource that demands efficient and careful management with a long time perspective.

A fundamental consideration when taking a decision on energy saving or energy transition, such as the introduction of solar energy, should thus be whether it will facilitate the sustainable management of the building, taking into account both long-term use and preservation. To achieve this, as with all other aspects of sustainable development, one must act from a perspective that aims to satisfy today's needs without it compromising the opportunities for future generations to satisfy theirs.

This fundamental tenet of the sustainability discourse is, not new. A similar philosophy was espoused by John Ruskin back in 1849 in his The Seven Lamps of Architecture, in which he describes older buildings thus: "They are not ours. They belong partly to those who built them and partly to all the generations of mankind who are to follow us."”

\section{Sustainability in cultural heritage buildings}

\subsection{A model}

The following is a development of Kohler's ${ }^{3}$ model for sustainability in the built environment, based on the three general dimensions of sustainability. Ecological values comprise embedded energy and the resource use of the building. Economic values are market value, running costs and revenues. Social values are functional values and cultural values. Cultural values are referred to as cultural heritage values which in turn are divided into documentary values and experiential values. The objective is not to add to the scientific discussion of these value categories, but rather position them in the overall context of the present paper.

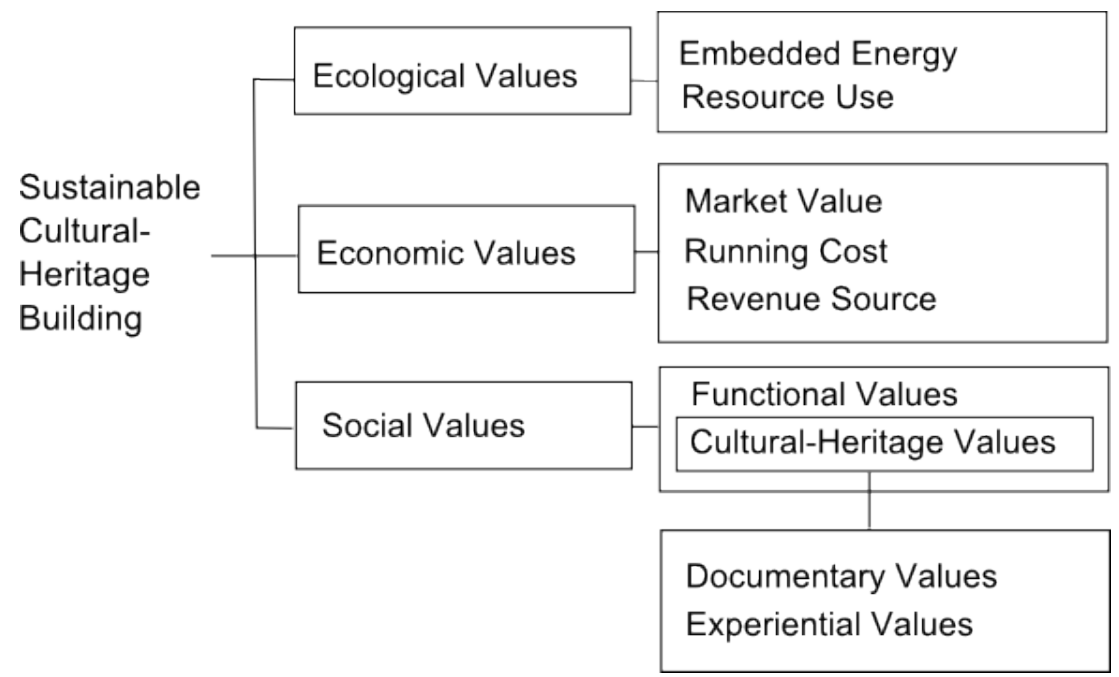

Fig 1: Conditions for sustainable cultural heritage buildings

If we are to achieve a truly sustainable management of buildings, we must take all three categories of values into account. A sustainable approach to the built heritage thus requires showing far-sighted consideration for all value categories, seeking balance between them, and understanding that they are mutually dependent rather than isolated quantities. ${ }^{1}$ Such management demands the identification of the built environment's values in order to ascertain how they are affected by change. In the following section the three value categories are discussed in a generic way, with a focus on the dependency between cultural heritage values and the two other value categories. 


\subsection{Social values}

Social values help to promote human wellbeing and can be broken down into functional and cultural-heritage values. All building types embody functional values, which is to say values that help to fulfil people's practical, aesthetic and symbolic needs.

The built heritage also contains cultural values, which, like their functional counterparts, contribute to human wellbeing. However, these latter values can also be of more overarching significance to sustainable development. The Faro Convention defines European cultural heritage as a resource for memory, understanding and identity.

The functional value of a building would generally increase with the use of solar energy. In some building where there are no viable options, for example unheated buildings with moisture problems, the use of solar energy can have a strong positive effect.

Cultural-heritage values can be divided into documentary and experiential values. The documentary value is associated with the building's function as source material - which on examination and analysis can yield information about the past - and chiefly comprises traditional value criteria based on historical knowledge (e.g. architectural-historical and personal-historical value). Estimating the documentary value of a building or built environment requires a degree of prior knowledge of the observer.

Experiential values are, by definition, more subjective than documentary values, and focus on the architectonic and aesthetic expression of a building or built environment. Experiential values are based mainly on immediately perceivable properties and qualities that thus require no prior knowledge to appreciate. Experiential values include architectonic value, artistic value, patina, environmental value and continuity value.

In the short term, the use of solar energy would have a negative effect on cultural heritage values. It is important to differentiate between irreversible effects on documentary values and reversible effects on experiential values. Ultimately, the fundamental cultural heritage values are dependent on the long term use and preservation of the building and thus on all other values.

\subsection{Economic values}

The economic aspects that are to be considered for a sustainable building management are market value, running cost and revenue. In addition to that we need to consider communal values related to the building in its context.

The market value of the building depends, of course, on running costs and revenues. Culture heritage values generally have a positive effect on the market value, even though this relation hardly lends itself to be quantified.

Revenue values, through direct utilisation (e.g. entrance fees) or indirect utilisation (restaurants, hotels and dwelling), are affected by culture heritage value in the same way as market values are.

Running costs are usually the main driving force when it comes to energy efficiency measures. High running costs can jeopardise the building's use or maintenance, which can lead to disrepair and dilapidation. This can reduce its value as a building as both its functional and market value are brought down, which, in the long run, will impact on its culturalheritage value. 
On being classified as "cultural heritage”, a building undergoes a process of commoditisation to become a product, by which is meant an item or phenomenon possessing economic value. The "cultural capital" of a town or region has become an important resource in the scramble to attract desirable businesses and consumers with purchasing power, competition in which cultural heritage is exploited as a product around which the image and character of the area can be assembled. Such marketing also enables a property owner to use a building's culturalheritage values in order to offer business and residential space that appear more attractive than offices and houses lacking such value. ${ }^{4}$ Cultural-heritage values can thus be a factor that boosts the market value of a building, but if the building, by virtue of such a classification, is granted legal protection, the effect can be the opposite in that its market value drops. ${ }^{5}$ It is not only the owner of such a building who can profit from its cultural heritage status; since property prices are location-bound and thus determined, for example, by the qualities of the cultural heritage environment, neighbouring buildings can also benefit. A change in the qualities that characterise an environment can thus impact upon the market value of other buildings in the vicinity.

That the market value of a built environment increases by virtue of the experiential values to which other buildings of cultural-heritage value give rise can therefore be seen as an externality, i.e. a side-effect that is of benefit to a third party. The built heritage can also generate other kinds of externalities, such as tourism, jobs and regional development ${ }^{5}$, and in so doing contribute to national economic growth. In this way, the building, even if privately owned, can serve as a kind of collective utility and thus as something that benefits the wider community. ${ }^{6}$

\subsection{Ecological values}

Part of the ecological value is the embedded energy. The building is a non-renewable resource that, like other non-renewable resources, should be managed efficiently and carefully. Existing buildings can be seen as ecological capital comprising different type of construction materials, the consumption needs of which can be limited by their preservation, maintenance and continuing use. This also reduces the need for energy-demanding newbuilds.

The other part of the ecological values is related to the use of energy and other resources. Prudent energy efficiency measures can make this kind of building more energy efficient as well, and thus increase its value as a resource for sustainable development.

The use of non-renewable resources would in most cases decrease with use of solar energy, adding to the ecological value. More importantly, a sustained use of the building would make a continued use of the energy embedded in the building.

\section{The impact of solar energy installations on a buildings values}

A decision to introduce solar energy is usually motivated with an expected increase in the building's economical, ecological or functional value. At the same time, the installations risk damaging the cultural-heritage value of the building and/or its surroundings which in turn could have an effect on the other values.

A decision not to introduce solar energy has the least impact on the cultural heritage value, in the short term. However it will reduce the ecological values. More important is that a nondecision in the long term may reduce economic and functional values even to the point where it might eventually threaten the use and condition of the building and thus also more fundamental cultural-heritage value. 
This line of reasoning sheds light on two aspects of the point at issue: firstly, the various value categories are, in different ways and to different degrees, interdependent, which means that the preservation or reinforcement of all value categories is a decisive factor in achieving the goal of long-term use and preservation of the built heritage. Secondly, it shows how vulnerable the value categories are to mutual conflict. The decision-making process therefore demands of the various actors involved an ability to take judicious decisions that can help to optimise the preservation of the different values of the building or the built environment. Looking solely to the cultural-heritage values in such a situation, for example, can ultimately damage opportunities for a building's long-term use and preservation, which can have a knock-back effect on its cultural-heritage value. Decisions on energy measures for buildings of cultural-heritage value therefore require a conscious and insightful balance of priorities between the various value categories of the building in question.

\section{Risk assessment}

Having identified the various values of a building, a risk analysis can be made in order to assess the short and long-term effects of a proposed change on all the value categories. A similar analysis should also be conducted on the basis of a no-installation scenario in which no change is made.

A simple risk-benefit matrix, see Fig 2, can be used to identify different types of problems. In cases with a low benefit or a high risk, marked in red, one should be restrictive. Low risk and high benefit, marked in green, is generally a win-win situation. Cases involving medium risk and medium to high benefit, marked in yellow, would probably need more attention.

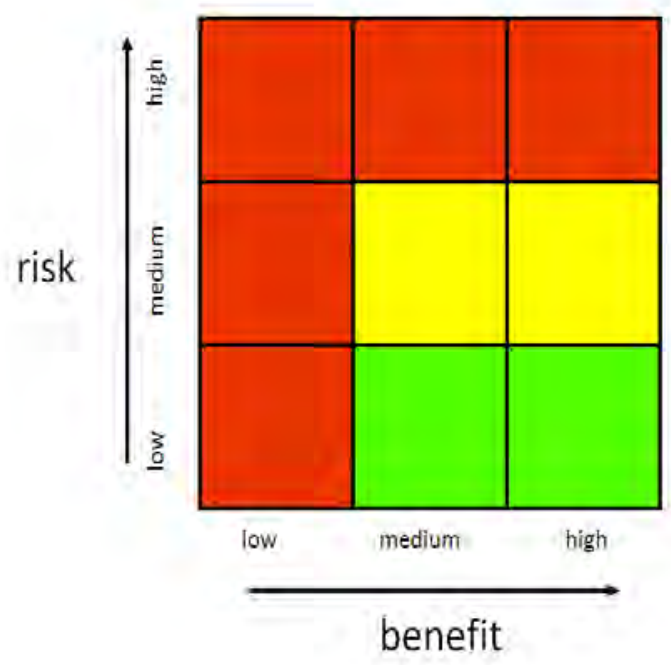

Fig 2: A matrix for a risk - benefit analysis

\section{Two generic examples}

\subsection{A medieval church.}

From a technical point of view, the steep and large south facing roof are a good place for solar collectors or solar cells, see fig 3. Depending in the alternatives, the use of solar energy adds to the ecological value in most cases. Depending on the investment, there might also be an economic value added in a lower energy cost. The visible impact would be considerable 
and, for most people, have a negative effect on the experiential cultural heritage value of the church as well as its surroundings. The document value of the building need not necessarily be affected, if installations are made in a careful and reversible manner.

If solar cells are used to produce electricity for the grid, one should consider the option of producing electricity somewhere else. If this is an option, the only benefit of installing solar cells on the church roof would be an added symbolic value, allowing the church to make a green statement. Thus there is a low or medium risk and small benefit.

In the case of a church with moisture problems, mould is a common, solar panels could be used for conservation heating. This would add to, or at least secure, the functional value as mould may render a building unfit for use. In the long term, the use of the building is the most important factor for a sustained preservation of the building and it's cultural heritage values. Here, the use of solar heating would have a positive and maybe decisive effect on the functional and cultural heritage values of the building. Thus there would a high benefit, and a low to medium risk.
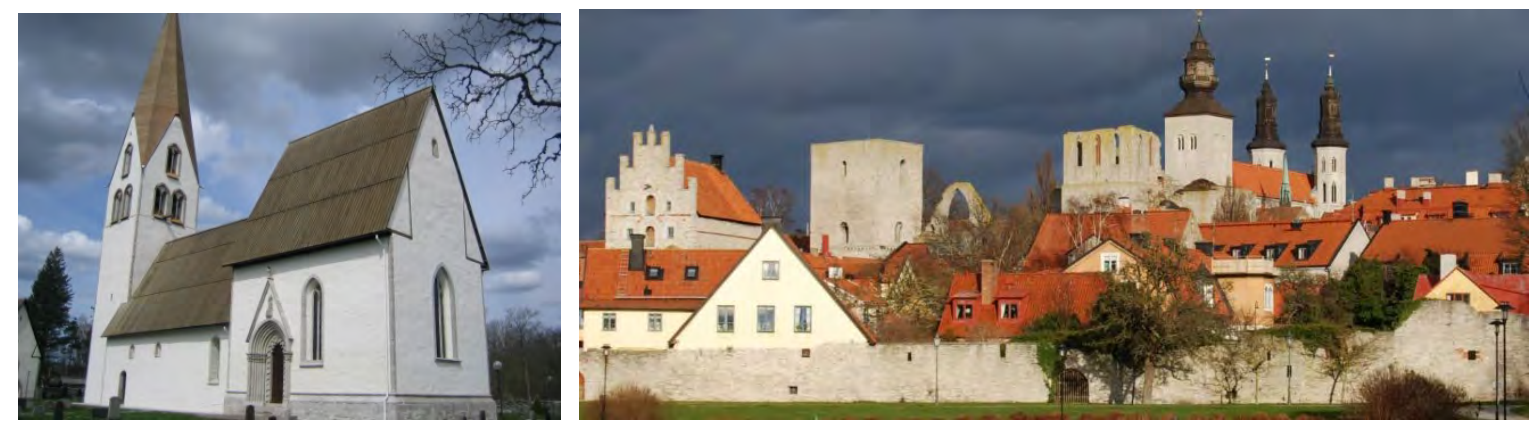

Fig 3 An illustration of the examples, a medieval church and the roofscape of Visby

\subsection{A hotel in a World Heritage town.}

The Hanseatic town of Visby on the island of Gotland is a world heritage site:

"A former Viking site on the island of Gotland, Visby was the main centre of the Hanseatic League in the Baltic from the 12th to the 14th century. Its 13th-century ramparts and more than 200 warehouses and wealthy merchants' dwellings from the same period make it the best-preserved fortified commercial city in northern Europe." ${ }^{7}$

A small family hotel situated in the Visby wants to use solar energy to produce hot water in the tourist season. The main building has a large south facing roof well suited for solar collectors, but it is also well visible to the public. The use of solar energy would add to the ecological value in most cases. The added economic value is significant since any other option would give a high investment in relation to the short period of use. The building itself is ordinary, the risk is associated with the visible impact on the roofscape of the city, se fig 3. As the installation would be visible Visby has a lot of visitors, the overall effect on the experiential value would be high. In the long term, extensive solar energy installation could have a negative effect on tourism, thus reducing the economic viability of both the hotel and the city. Thus we have both a high risk and high benefit. A more depth investigation of this case should focus on optional solutions, either finding a less visible location for the solar collectors or another source of energy. 


\section{Closing discussion}

The management of the built cultural heritage should strive to ensure its posterity to future generations. Since the value categories of buildings are mutually dependent, long-term use and preservation require a management process that takes their economic, ecological and social values into consideration.

It is thus impossible to provide a general answer to the question of whether the installation of solar energy technology should be considered a measure that contributes to the long-term use and preservation of a building of cultural-heritage value, or whether it constitutes a threat to the cultural-heritage values that make the building or the built environment worth preserving in the first place. This is a judgement call that must be made on a case-by-case basis by weighing the potential risks and benefits (fig. 4). Should the risks be deemed relatively high, installation should not proceed. Conversely, if the benefits are relatively high, installation can be considered appropriate. However, the most problematic cases arise when both the risks and benefits of solar energy are equally high. These cases require a thorough impact analysis to ascertain the best action to take in the interests of long-term use and preservation.

Much of the debate around solar energy and built heritage concerns individual cases. A challenge for the future is to seek a more coordinated, inter-sector planning and decisionmaking process based on a holistic view of the built environment. Such a process should take account of all the value categories represented in the building in question and the environment in which it stands. Involving all concerned parties at an early stage of the process and identifying all values makes it possible to create a planning and decision-making process with clear allocations of rights and responsibilities. This, in its turn, will enable an assessment of the positive and negative consequences an installation might have for the various value categories, and thus of which decision creates the most favourable opportunities for the sustained use and preservation of the building and the built environment.

\section{References}

[1] D. Throsby, "Culture, economics, sustainability”, Journal of Cultural Economics, 19 (3) (1995).

[2] J. Ruskin, The seven lamps of architecture (London: Allen \& Unwin 1925).

[3] N. Kohler, "The relevance of green building challenge: an observer's perspective", Building Research \& Information, 27 (4/5) (1999) pp 309-20.

[4] J. Grundberg, Kulturarvsförvaltningens samhällsuppdrag: en introduktion till kulturarvsförvaltningens teori och praktik (The Character of Cultural Heritage Management and its Public Agenda), Lic. Thesis, (Department of Archaeology, Gothenburg University, 1999).

[5] M. Hutter, "Economic Perspectives on Cultural Heritage: An Introduction”, Economic perspectives on cultural heritage (Basingstoke : Macmillan, 1997) p.16.

[6] K. Olsson, Från bevarande till skapande av värde: kulturmiljövården i kunskapssamhället, $\mathrm{PhD}$ thesis, (Royal Institute of Technology, Department of Urban Planning and Environment, Stockholm, 2003).

[7] UNESCO World Heritage List. http://whc.unesco.org/pg.cfm?cid=31\&id_site=731 